\title{
An easterly tip jet off Cape Farewell, Greenland. I: Aircraft observations
}

\author{
I. A. Renfrew, ${ }^{a} *$ S. D. Outten ${ }^{\mathrm{a}}$ and G. W. K. Moore ${ }^{\mathrm{b}}$ \\ ${ }^{a}$ School of Environmental Sciences, University of East Anglia, Norwich, UK \\ ${ }^{\mathrm{b}}$ Department of Physics, University of Toronto, Canada
}

\begin{abstract}
An easterly tip jet event off Cape Farewell, Greenland, is described and analysed in considerable detail. In Part I of this study (this paper) comprehensive aircraft-based observations are described, while in Part II of this study numerical simulations and a dynamical analysis are presented. The easterly tip jet of 21 February 2007 took place during the Greenland Flow Distortion experiment. It resulted through the interaction of a barotropic synoptic-scale low pressure system in the central North Atlantic and the high topography of southern Greenland. In situ observations reveal a jet core at the coast with peak winds of almost $50 \mathrm{~m} \mathrm{~s}^{-1}$, about $600-800 \mathrm{~m}$ above the sea surface, and of $30 \mathrm{~m} \mathrm{~s}^{-1}$ at $10 \mathrm{~m}$. The depth of the jet increased with wind speed from $\sim 1500 \mathrm{~m}$ to $\sim 2500 \mathrm{~m}$ as the peak winds increased from 30 to $50 \mathrm{~m} \mathrm{~s}^{-1}$. The jet accelerated and curved anticyclonically as it reached Cape Farewell and the end of the barrier. The easterly tip jet was associated with a tongue of cold and dry air along the coast of southeast Greenland, general cloud cover to the east, and cloud streets to the south of Cape Farewell. Precipitation was observed during the low-level components of the flight. The very high wind speeds generated a highly turbulent atmospheric boundary layer and resulted in some of the highest surface wind stresses ever observed over the ocean. Copyright (c) 2009 Royal Meteorological Society
\end{abstract}

KEY WORDS Greenland Flow Distortion experiment (GFDex); barrier wind; topographic flow

Received 8 January 2009; Revised 10 June 2009; Accepted 17 August 2009

\section{Introduction}

The coastal seas off Cape Farewell, the southernmost tip of Greenland, have recently been marked out as the windiest location in the world ocean (Sampe and Xie, 2007; Moore et al., 2008). The reason for this climatological accolade is the frequent low-level 'tip jets' that occur there as a result of interactions between the synoptic-scale flow and the high topography of Greenland. Westerly tip jets were first investigated, through numerical model simulations, by Doyle and Shapiro (1999), while easterly or reverse tip jets were first investigated by Moore (2003) and Moore and Renfrew (2005). Doyle and Shapiro suggested tip jets were driven by a Bernoulli acceleration as flow descended down the lee side of Greenland, as well as acceleration in the lee due to flow distortion around the tip of Greenland. A series of idealised modelling studies have emphasised more strongly the importance of the acceleration due to flow distortion around such obstacles; for example, Ólafsson and Bougeault (1996, 1997) and Petersen et al. (2003, 2005); while recent case-studies have also found a similar relative importance of flow distortion, rather than Bernoulli acceleration, e.g. Hay et al. (2009).

It has been hypothesised that the forcing mechanism of easterly tip jets is quite different; that these are in fact

\footnotetext{
*Correspondence to: I. A. Renfrew, School of Environmental Sciences University of East Anglia, Norwich, NR4 7TJ, UK.

E-mail: i.renfrew@uea.ac.uk
}

barrier flows which, upon reaching the end of the barrier at Cape Farewell, turn anticyclonically and accelerate into a curved gradient wind balance (Moore and Renfrew, 2005). In other words, they are barrier flows undergoing a rapid adjustment due to the removal of the barrier. Recall barrier flows result from air impinging upon a non-dimensionally high barrier (i.e. large $N h / U$, where $N$ is the Brunt-Väisälä frequency, $h$ is the barrier height and $U$ is the upstream velocity) and being forced to turn to an along-barrier flow that is broadly in geostrophic balance (e.g. Schwerdtfeger, 1975; Parish, 1982, 1983; Pierrehumbert and Wyman, 1985; Petersen et al., 2009). However it is likely that easterly tip jets are also related to the 'corner jets' described in the textbook of Godske et al. (1957) and often referred to subsequently as 'leftsided jets’ (e.g. Barstad and Grønås, 2005). The left-sided asymmetry here is due to a reduced Coriolis forcing as the flow decelerates in front of the barrier, leading to a pressure-gradient induced acceleration on the left side of the mountains (thus they are only left-sided in the Northern Hemisphere). These jets are a common feature of idealised numerical simulations (e.g. Ólafsson and Bougeault, 1997) and case-study numerical simulations of, for example, southern Norway (Barstad and Grønås, 2005) and Svalbard (Skeie and Grønås, 2000). It is an open question as to which dynamical forcing mechanisms dominate for Greenland's easterly tip jets ${ }^{\dagger}$. Note Sampe

†Note in recognition that Greenland's easterly tip jets are part of a larger class of topographic jets that include 'corner jets' and 'left-sided 
and Xie (2007) tabulate other locations prone to frequent gale force winds where high topography appears instrumental - e.g. Enderby Land (Antarctica), Cape Horn and southwest New Zealand (e.g. Revell et al., 2002) - and where one might surmise tip jets are prevalent.

The high winds associated with these mesoscale atmospheric features are a maritime hazard and - models have shown - can act as atmospheric forcing triggers for oceanic deep convection in the Irminger Sea (Pickart et al., 2003; Våge et al., 2008) and so play a role in the thermohaline circulation and thus the climate system. However, observations at the windiest location in the world ocean are, not surprisingly, rather rare. Almost all previous studies have relied exclusively on either satellite-based observations, such as scatterometer winds (e.g. QuikSCAT winds: Moore and Renfrew, 2005; Sampe and Xie, 2007), meteorological analyses or reanalyses (Moore, 2003; Egger, 2006), or numerical weather prediction (NWP) simulations (Doyle and Shapiro, 1999; Petersen et al., 2003, 2005; Orr et al., 2005; Martin and Moore, 2007; Ohigashi and Moore, 2009). The only exceptions are two recent studies that

jets'; here we use the adjective 'easterly' in preference to 'reverse' tip jet. This is because similar phenomena in other locations (e.g. Svalbard) are not necessarily 'reverse' to the climatological atmospheric flow direction - as is the case in southern Greenland.

(a)

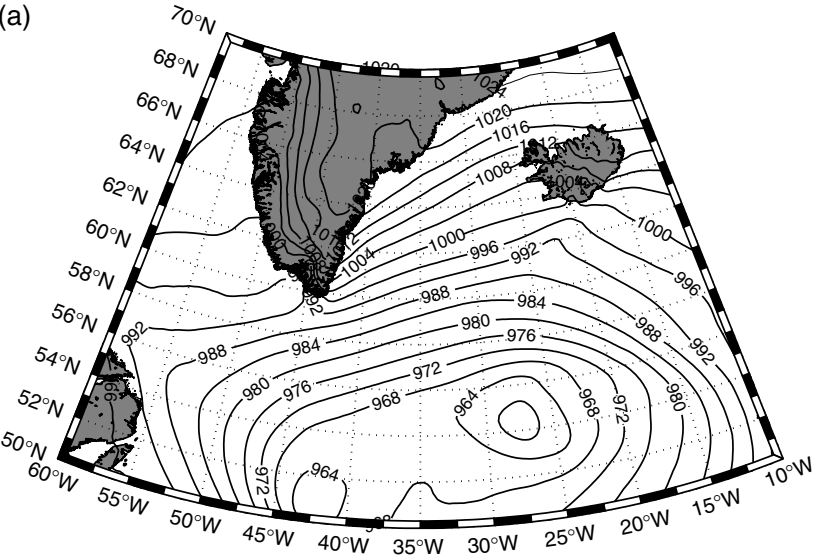

(c)

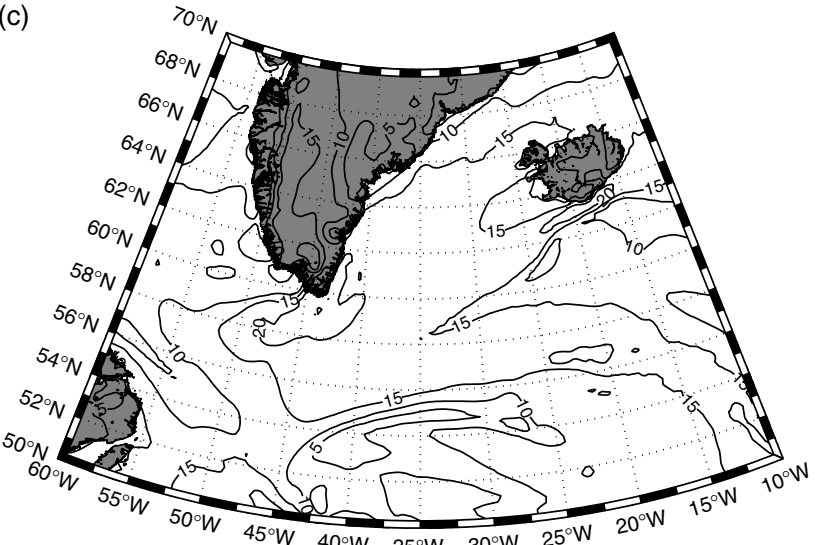

make use of a meteorological buoy located in the Irminger Sea from July to December 2004 (whereupon the buoy broke loose from its mooring and was blown around the North Atlantic, finally being rescued by the Icelandic Coastguard in May 2005), see Moore et al. (2008) and Hay et al. (2009). It is perhaps worth noting that a number of studies have made use of observations from the meteorological stations on the coast of Greenland itself (e.g. Cappelen et al., 2001; Pickart et al., 2003), although given the dramatic topography of the Greenland coast there are obviously representivity problems in extrapolating such data to over the ocean.

In this study we present the first comprehensive observations of a tip jet event, to be precise, the easterly tip jet (ETJ) of 21 February 2007. These comprise flight-level and dropsonde observations from mission B268 of the Greenland Flow Distortion experiment (GFDex). GFDex was primarily an aircraft-based field campaign focusing on the dynamics and air-sea interaction associated with tip jets, barrier winds and mesoscale cyclones in the coastal seas around Greenland, as well as a targeted observation programme and, of course, complimentary numerical modelling activities. Renfrew et al. (2008) provides an overview of GFDex; while other papers within this special issue focus on a number of related topics.
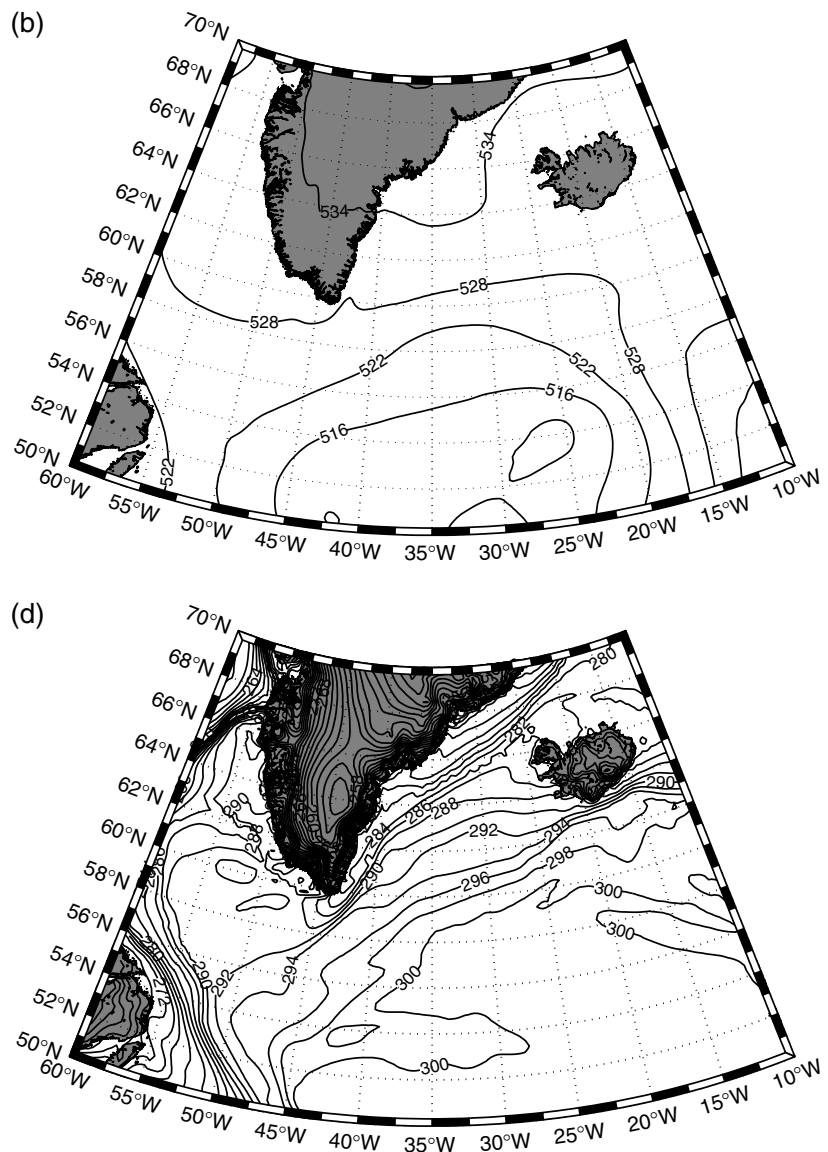

Figure 1. ECMWF operational analyses for 1200 UTC 21 February 2007. Panels show (a) mean-sea-level pressure, (b) 500 hPa geopotential height, (c) 10-metre wind speed, and (d) 2-metre equivalent potential temperature. Contour intervals are $4 \mathrm{hPa}, 6 \mathrm{dam}, 5 \mathrm{~m} \mathrm{~s}^{-1}$ and $2 \mathrm{~K}$ respectively. 


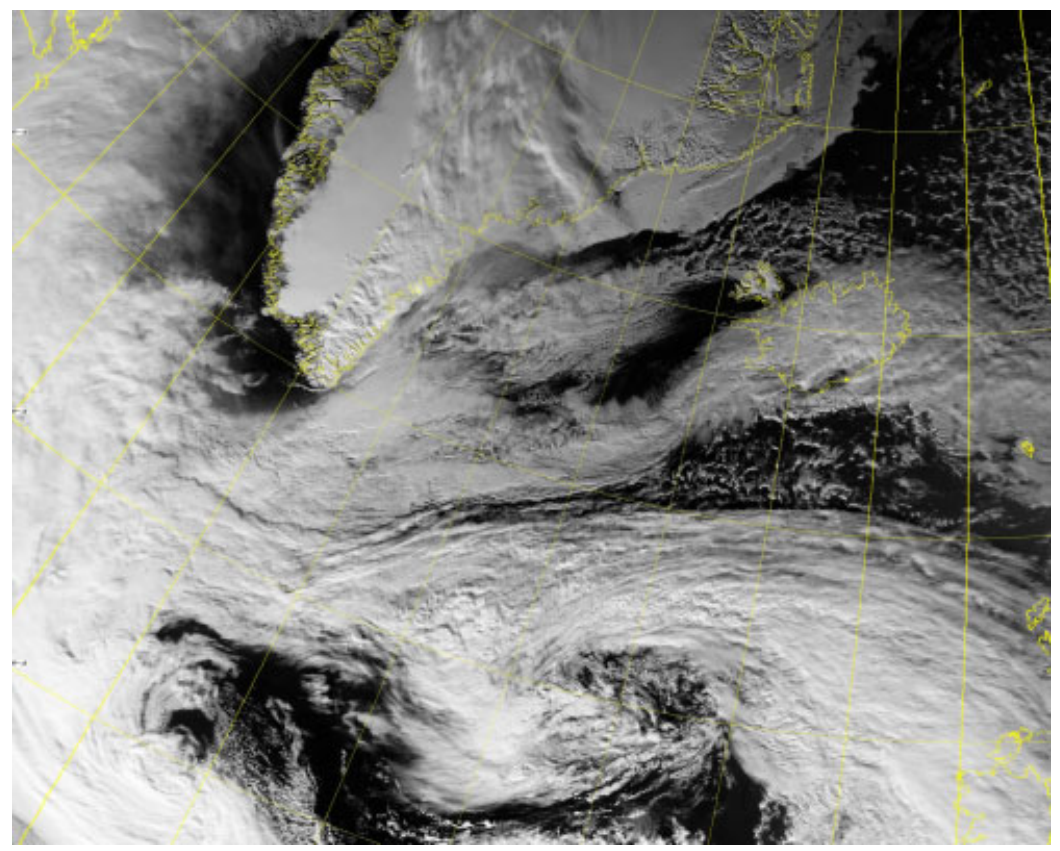

Figure 2. AVHRR visible (channel 1) satellite image from 1442 UTC 21 February 2007. Lines of latitude and longitude every 5 degrees are marked. Cyclonic cloud shields associated with the broad double-centred low pressure dominate the southern part of the image. A ribbon of cloud runs SW from Iceland associated with an occluded front. This figure is available in colour online at www.interscience.wiley.com/journal/qj

In Part I of this study a detailed analysis of the aircraft observations is presented; while in Part II results from numerical simulations are presented and validated before a thorough dynamical analysis is carried out (Outten et al., 2009, hereafter referred to as Part II).

In the next section the synoptic situation is summarised. Section 3 provides a brief description of the flight plan and relevant instrumentation details. Section 4 describes the dropsonde and flight-level observations. Section 5 provides a synthesis and discussion of these observations, with some conclusions in section 6 .

\section{Synoptic situation}

During 20 February 2007 a synoptic-scale low pressure system moved north from the central North Atlantic, settling around $40^{\circ} \mathrm{W}, 50-55^{\circ} \mathrm{N}$, with a central pressure of about $956 \mathrm{hPa}$. Over 21 February this low broadened zonally, at times with two analysed centres (see Figure 1(a)), but remained about the same depth. To the north of Scandinavia was a $1040 \mathrm{hPa}$ high. These two systems resulted in a broad easterly-to-northeasterly flow over much of the central North Atlantic during this period. The low pressure system was rather barotropic, for example being well-defined in $500 \mathrm{hPa}$ geopotential height at 1200 UTC 21 February (Figure 1(b)). Associated with this synoptic situation were several areas of high near-surface wind speeds. Figure 1(c) shows areas analysed with gale-force winds (greater than $20 \mathrm{~m} \mathrm{~s}^{-1}$ ) to the south of Cape Farewell $\left(45^{\circ} \mathrm{W}, 60^{\circ} \mathrm{N}\right)$ - the easterly tip jet (ETJ) - and also off the southeast coastline of Iceland. Other prominent features include a strong shear zone on the northern side of the low pressure centre $\left(\sim 54^{\circ} \mathrm{N}\right)$ and wake regions in the lee of both southern Greenland and Iceland. Figure 1(d) illustrates the analysed $2 \mathrm{~m}$ equivalent potential temperature at this time. There was a tongue of cold air, well defined by the $290-284 \mathrm{~K}$ isolines, hugging the southeast coast of Greenland. There were also strong temperature gradients off the coast of Labrador and at the sea ice edge about $66^{\circ} \mathrm{N}$ in the Labrador Sea.

Figure 2 shows an AVHRR (Advanced Very High Resolution Radiometer) visible satellite image from 1442 UTC 21 February 2007. The image is dominated by the cyclonic cloud associated with the broad synoptic-scale low. The double-centre in mean-sea-level pressure is also reflected as two cyclonic cloud signatures. To the north of the low there was a ribbon of mid-level cloud stretching south-westwards from Iceland. This feature was analysed as an occluded front in operational analyses (not shown) and was associated with a moderate temperature gradient (Figure 1(d)). There was a clear wake region in the lee of northwest Iceland, with more mid-level cloud between there and southeast Greenland - some of which appears convective in origin. Much of Greenland itself appears to be cloud free; one can clearly see the ice sheet on the southwest side (as well as the surface of the eastern Labrador Sea), the coastal mountains to the northeast and sea ice along the eastern coastline. The area of the tip jet is predominantly covered by mid-level cloud, although this dissipates at Cape Farewell itself, revealing low-level cloud streets underneath.

Figure 3 provides a close-up of this area from the same satellite pass. One can see that the mid-level cloud associated with the tip jet is densest some way off the coastal mountains; indeed there are clearer slots at, and parallel to, the coast. South of $\sim 59^{\circ} \mathrm{N}$, and north of $\sim 62^{\circ} \mathrm{N}$ (near 


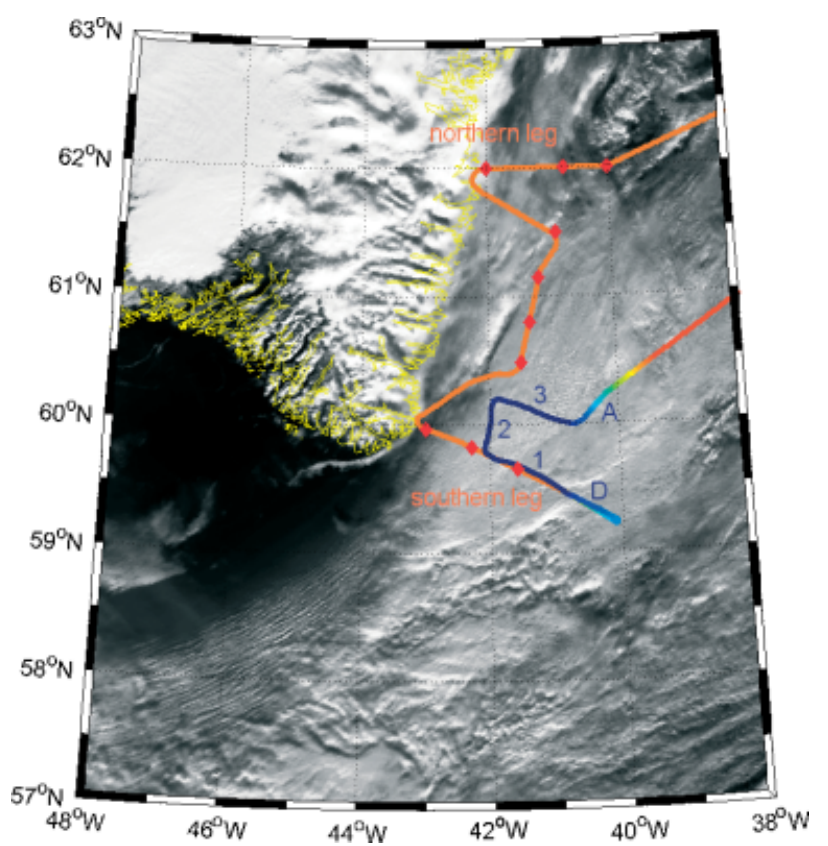

Figure 3. A close-up of the visible image in Figure 2 from 1442 UTC 21 February, focusing on the area of the easterly tip jet. Overlaid is part of the flight track of mission B268, at about $5500 \mathrm{~m}$ or about $40 \mathrm{~m}$ above the sea surface. Dropsonde locations are marked as diamonds. The upper-level 'northern' and 'southern' legs are labelled, as are the aircraft's decent (D), low-level legs 1, 2 and 3, and the ascent (A). the sea ice edge) the clouds appear more convective in nature. Close examination of the mid-level clouds of the ETJ $\left(\sim 41^{\circ} \mathrm{W}, 60^{\circ} \mathrm{N}\right)$ reveals banded features in the cloud, most likely associated with gravity waves. Curving anticyclonically to the south of Cape Farewell there are clearly cloud streets caused by roll vortices in the atmospheric boundary layer (ABL), see for example Atkinson and Zhang (1996). Cloud streets are characteristic of coldair outbreaks and align approximately in the direction of the low-level wind (e.g. Renfrew and Moore, 1999); thus Figure 3 suggests an anticyclonic low-level flow where they are present. There is also an unusual cloud 'streak' curving anticyclonically away from Cape Farewell itself, possibly a banner cloud (Schween et al., 2007), which again suggests anticyclonic low-level flow. To the west of southern Greenland the sea surface is apparent in a cloudfree wake region (cf. Figure 1(c)). The infrared (channel 4) image at the same time has also been examined and illustrates many of the same features (not shown).

\section{Mission details}

\subsection{Flight plan}

A comprehensive upper- and low-level survey of the ETJ feature of 21 February 2007 was carried out on the first
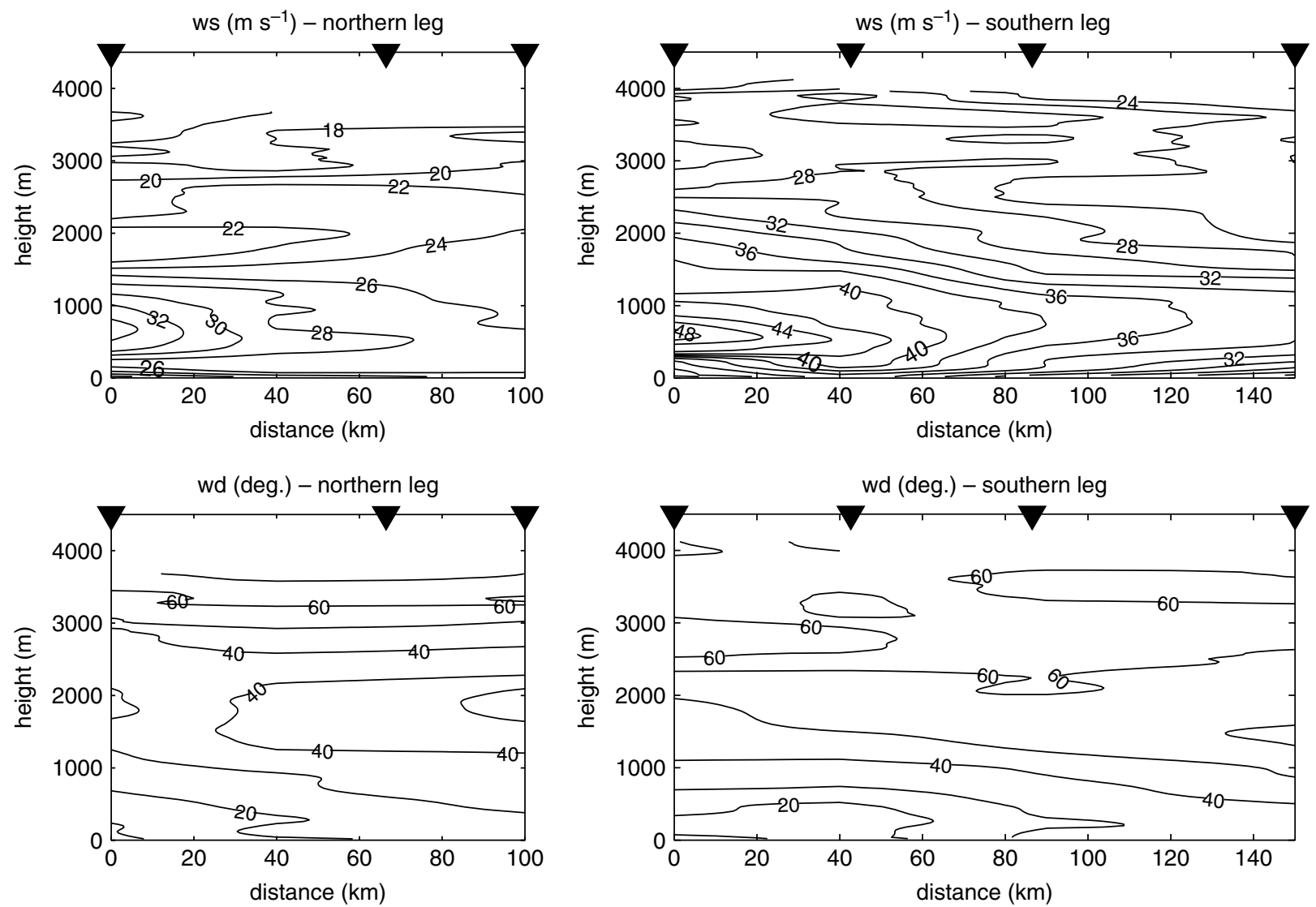

Figure 4. Cross-sections of wind speed (ws) and wind direction (wd) for the northern and southern high-level legs based on dropsonde soundings (see text for details). The locations of the soundings are marked as solid triangles at the top of each panel. The distance axis is eastwards, away from the Greenland coast. Contours are drawn every $2 \mathrm{~m} \mathrm{~s}^{-1}$ and every 10 degrees. 

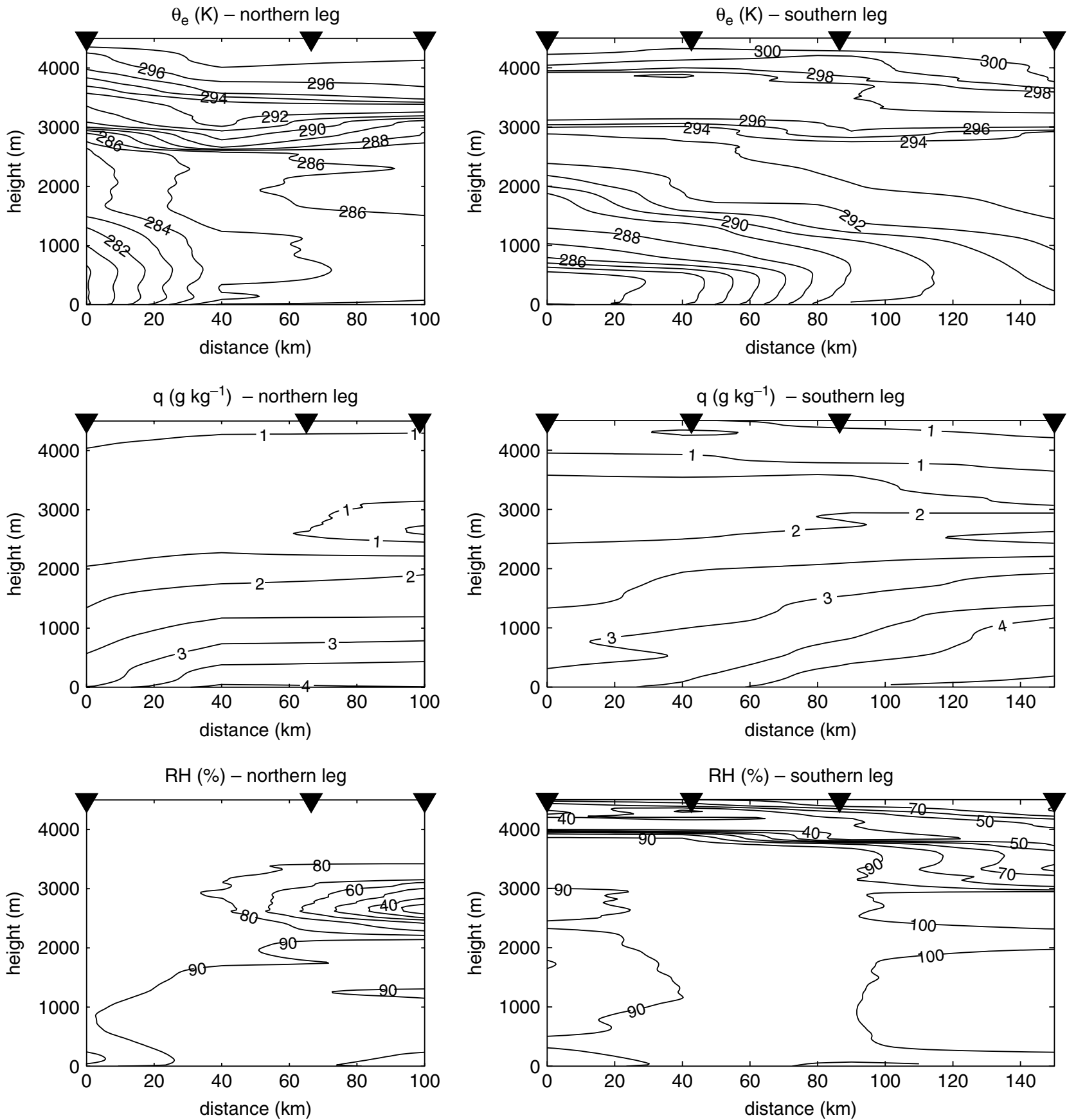

Figure 5. Cross-sections of equivalent potential temperature $\left(\theta_{\mathrm{e}}\right)$, specific humidity $(q)$ and relative humidity $(\mathrm{RH})$ for the northern and southern high-level legs - as in Figure 4. Contours are drawn every $1 \mathrm{~K}, 0.5 \mathrm{~g} \mathrm{~kg}^{-1}$ and $10 \%$.

instrumented flight of the GFDex field campaign (mission B268). GFDex made use of the UK Facility for Airborne Atmospheric Measurements' (FAAM's) BAE 146 jet. A campaign summary for GFDex, including a short synopsis of this case, along with details of the FAAM aircraft and its 'core' instrumentation during GFDex, is provided in Renfrew et al. (2008). Overlaid on Figure 3 is the central part of the flight track of B268; note the flight took off and returned to Keflavík, Iceland. The flight plan consisted of an upper-level $(18 \mathrm{kft} \approx 5500 \mathrm{~m}$ above sea level) survey of the jet feature, flying west at $62^{\circ} \mathrm{N}$ - the 'northern leg', then down the jet core parallel to the coastline with heading 190 degrees, and then back across the jet leaving the coast at $\sim 60^{\circ} \mathrm{N}$ with heading $\sim 120$ degrees - the 'southern leg'. Twelve dropsondes were released during these upper-level legs, four on each leg; unfortunately, however, dropsondes 3 and 12 failed to report any measurements. The positions of the working dropsondes are marked on Figure 3 with diamonds. The flight plan continued with a profile descent to minimum safe altitude, in this case $35-50 \mathrm{~m}$, on the same heading with a 180 degree turn at about $1800 \mathrm{~m}$ altitude. The low-level mission comprised three low-level legs, the first, about $70 \mathrm{~km}$ in length, being flown underneath the last upper-level leg (see Figure 3). Poor visibility forced us to terminate this leg at $42^{\circ} \mathrm{W}$ for safety reasons. 

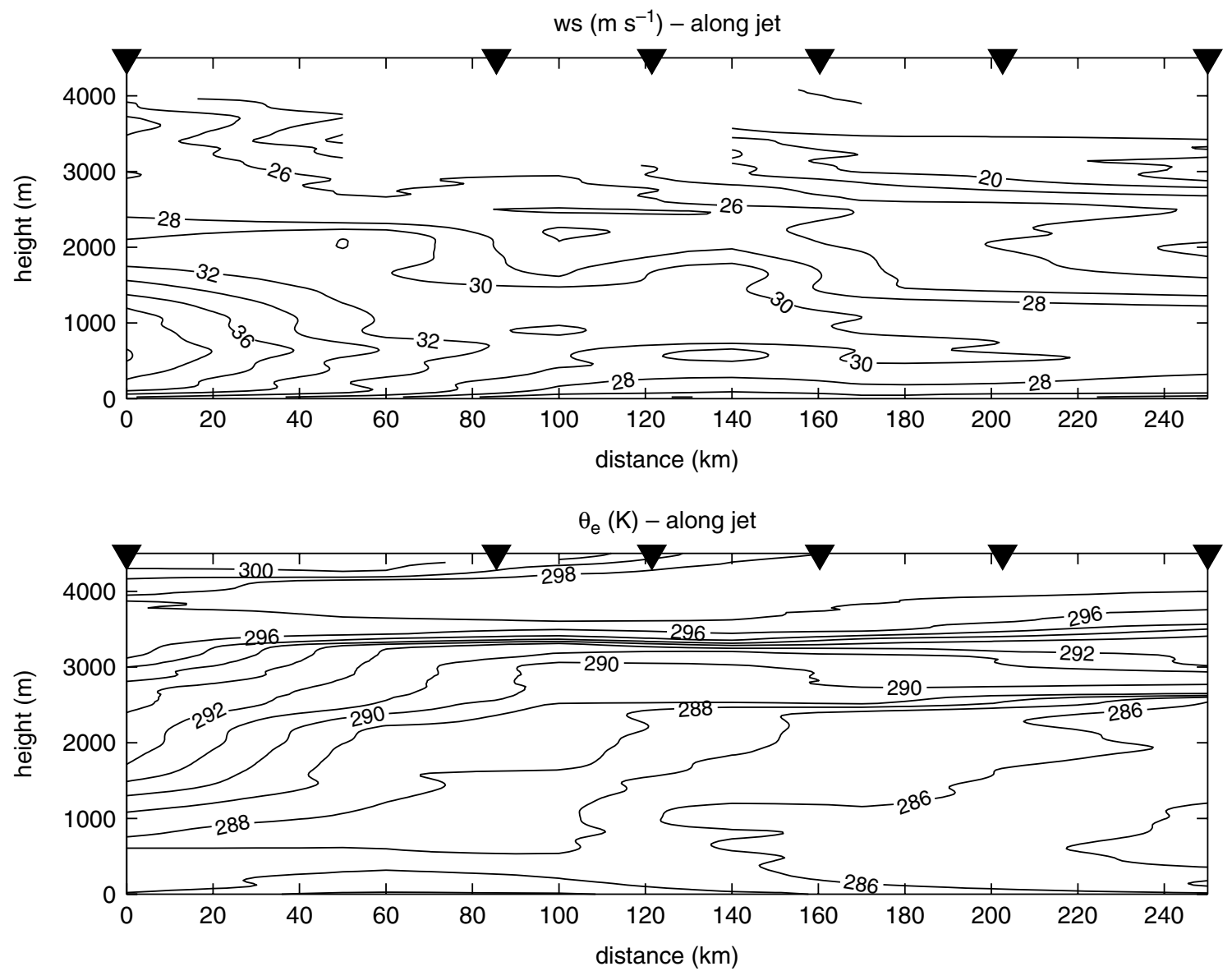

Figure 6. Cross-sections of wind speed (ws) and equivalent potential temperature $\left(\theta_{\mathrm{e}}\right)$ along the jet. The distance axis is northwards. Contours are drawn every $2 \mathrm{~m} \mathrm{~s}^{-1}$ and every $1 \mathrm{~K}$.

Low-level leg 2 was about $50 \mathrm{~km}$ in length heading north, with leg 3 about $65 \mathrm{~km}$ in length on heading 120 degrees (parallel to leg 1). A profile ascent was made at the end of leg 3 . Note the time sampling the tip jet was only about 2 hours - from 1220 UTC, the first dropsonde, till 1424 UTC, the profile ascent. Hence the aircraft observations can essentially be viewed as an instantaneous snapshot.

\subsection{Instrumentation}

A description of the FAAM's core instrumentation is provided in Renfrew et al. (2008) and on the facility website (www.faam.ac.uk). A brief summary of the key instruments for flight B268 is included here:

- Air temperature was measured with Rosemount temperature sensors (non de-iced and de-iced). Unfortunately during the turn in the profile descent the temperature sensors were 'wetted' and from this point onwards were therefore unreliable; in effect they were recording a wet-bulb temperature rather than a dry-bulb temperature.

- Humidity was measured using a Lyman-alpha absorption hygrometer, which measures total water content with an uncertainty of $\pm 0.15 \mathrm{~g} \mathrm{~kg}^{-1}$. The response of this instrument changes with time, which means it has to be carefully calibrated using the fitted General Eastern cooled-mirror hygrometer.

- A five-port turbulence probe on the nose of the aircraft, in conjunction with data from the Inertial Navigation Unit and other navigational aids, provided three-dimensional wind velocities with a standard overall uncertainty of less than $\pm 0.5 \mathrm{~m}$ $\mathrm{s}^{-1}$. Note that air temperature is used as part of the velocity calculations. Tests of the velocity algorithm have shown that errors of $5 \mathrm{~K}$ in temperature would lead to errors in wind speed of order $1 \mathrm{~m}$ $\mathrm{s}^{-1}$. A check against dew-point temperature measurements suggests the temperature wetting errors are typically half of this, implying, for this flight, overall horizontal wind uncertainties of $\pm 1 \mathrm{~m} \mathrm{~s}^{-1}$.

- Flight-level altitude was measured by Global Positioning System (GPS) (relative to the WGS84 geoid) and corrected to geometric height by (in this case) subtracting a constant $50 \mathrm{~m}$.

- Two-dimensional cloud (2DC, 25-800 $\mu \mathrm{m}$ ) and precipitation (2DP, 200-6400 $\mu \mathrm{m}$ ) particle imaging probes measured particle number concentration, condensed water content, image shape, etc. In addition, liquid water content was also measured by a Johnson-Williams heated wire resistance bridge 
and by a Nevzorov heated wire, both over a range of $0-3 \mathrm{~g} \mathrm{~m}^{-3}$ and with an uncertainty of $\pm 10 \%$.

An AVAPS (Airborne Vertical Atmospheric Profiler System) was installed on the FAAM from which GPS dropsondes (Vaisala RD93) were deployed. These measured position, altitude, pressure, temperature and relative humidity $(\mathrm{RH})$ at $2 \mathrm{~Hz}$ and calculated wind speed and wind direction. On B268 all dropsondes terminated at the sea surface, which enabled the GPS-determined altitude to be corrected from the ground upwards. The dropsonde data were quality-controlled using the ASPEN dropsonde software (available from NCAR - the National Center for Atmospheric Research, Colorado). The quality-control procedures involved outlier checks (using 10 standard deviations for each variable), filtering of suspect data points, pressure smoothing, temperature dynamic adjustment and wind dynamic adjustment. Buddy checks were applied for pressure, temperature, $\mathrm{RH}$ and the winds using thresholds per second of $2 \mathrm{hPa}, 3^{\circ} \mathrm{C}, 20 \%$ and $5 \mathrm{~m}$ $\mathrm{s}^{-1}$ respectively; a 10 -second filter was also applied to the same variables with deviation limits of $3 \mathrm{hPa}, 3^{\circ} \mathrm{C}$ $3 \%$ and $3 \mathrm{~m} \mathrm{~s}^{-1}$. There is a final smoothing over a $5 \mathrm{~s}$ period (10 s for winds). Note that these dropsondes typically fall at about $10 \mathrm{~m}$ per second. The accuracy (repeatability) of the soundings is $0.4 \mathrm{hPa}, 0.1^{\circ} \mathrm{C}, 2 \%$ and $0.5 \mathrm{~m} \mathrm{~s}^{-1}$ for pressure, temperature, $\mathrm{RH}$ and winds respectively. Further details on the quality-control procedures can be found in the ASPEN User Manual (Martin, 2007).

\section{Observations}

Observations from the dropsonde soundings have been used to create vertical cross-sections of the easterly tip jet. Dropsondes 1,2 and 4 are used for the northern cross-section at $62^{\circ} \mathrm{N}$; dropsondes $2,5,6,7,8$, and a linear interpolation of dropsondes 10 and 11 for an along-jet cross-section parallel to the coast; and dropsondes 9, 10, 11 and the aircraft's descent for the southern cross-section (see Figure 3). The aircraft's profile descent has been derived from $1 \mathrm{~Hz}$ flightlevel data. To remove the rapidly varying turbulence signature in these observations a non-causal $10 \mathrm{~s}$ moving point average filter has been applied. This results in an aircraft-based 'pseudo-sounding' filtered to a similar degree as the dropsonde soundings. As noted above, the aircraft's temperature sensors became 'wetted' during this descent at a height of about $2000 \mathrm{~m}$. Examination of the temperature $(T)$ and dew-point temperature $\left(T_{\mathrm{d}}\right)$ profiles suggests that towards the end of the descent these sensors dried out ( $T>T_{\mathrm{d}}$ at this point) so for illustrative purposes a linear interpolation of $T$ between 2000 and $50 \mathrm{~m}$ was used in the southern cross-section. Note that a very similar plot results if it is assumed $T=T_{\mathrm{d}}$ during this part of the descent - a reasonable assumption given the aircraft is in cloud. To generate the cross-sections the soundings are linearly interpolated onto a regular height grid of resolution $20 \mathrm{~m}$ and smoothed using a 5-point noncausal moving point average filter which removes some of the smaller-scale variability of that sounding (e.g. see Figs. 3-5 in Part II).

Figure 4 shows wind speed and wind direction, while Figure 5 shows equivalent potential temperature $\left(\theta_{\mathrm{e}}\right)$, specific humidity $(q)$ and relative humidity $(\mathrm{RH})$ for the cross-jet sections. The ETJ was well defined as a lowlevel maximum in wind speed, with the maximum winds at the coast. Peak wind speeds were over $32 \mathrm{~m} \mathrm{~s}^{-1}$ in the northern section and over $48 \mathrm{~m} \mathrm{~s}^{-1}$ in the southern section, with the jet maximum about 600-800 $\mathrm{m}$ above sea level. The jet was relatively deep, reaching up to $\sim 1500 \mathrm{~m}$ in the northern leg and over $2500 \mathrm{~m}$ in the southern leg. The jet was clearly deeper where it was stronger, as illustrated by following, for example, the $32 \mathrm{~m} \mathrm{~s}^{-1}$ isotach offshore from $2400 \mathrm{~m}$ to $1400 \mathrm{~m}$ in the southern leg. The same is clear in the along-jet crosssection, for example the $28 \mathrm{~m} \mathrm{~s}^{-1}$ isotach increases from a height of $1400 \mathrm{~m}$ to $2400 \mathrm{~m}$ along the jet (Figure 6). The jet also led to very strong winds near the surface, such as between 40 and $80 \mathrm{~km}$ in the southern leg, although note that the sounding near the coast had a more wellmixed surface layer - perhaps due to greater surface drag at this location. The jet's wind direction increased from 20-30 degrees near the surface, to 30-50 degrees in the jet core and above. There is little change in wind direction between the two cross-jet sections or in the along-jet cross-section (not shown).

Figure 5 shows both cross-jet sections have a horizontal gradient in $\theta_{\mathrm{e}}$, with cold air 'piled up' against the coast. For example, in the southern cross-section $\partial \theta_{\mathrm{e}} / \partial x=1$ $\mathrm{K} / 50 \mathrm{~km}$ at $\sim 2000 \mathrm{~m}$ above the sea surface. There was a stronger horizontal gradient $(\sim 6 \mathrm{~K} / 50 \mathrm{~km})$ at the edge of the tongue of cold air along the coast, e.g. delineated by $\theta_{\mathrm{e}}<284 \mathrm{~K}$. This feature is consistent with the cold-air tongue noted in the ECMWF operational analyses (Figure 1(d)); although the ECMWF analyses does not capture the very coldest air $\left(\theta_{\mathrm{e}}<282 \mathrm{~K}\right)$ seen in the northern cross-section. This tongue of cold air is $\sim 1500 \mathrm{~m}$ deep at the northern section and $\sim 1000 \mathrm{~m}$ deep at the southern section. Note there is a maximum in $\partial \theta_{\mathrm{e}} / \partial z$ at a height of around $3000 \mathrm{~m}$ in all the crosssections (Figures 5 and 6), suggesting a relatively deep ABL of $\sim 3000 \mathrm{~m}$. Hence the tongue of cold air does not occupy the entire ABL, only the lower half. Such deep ABLs are not uncommon during marine cold air outbreaks; see e.g. Renfrew and Moore (1999) or Brümmer (1997). Below 100-500 m (depending on the location) there was a relatively deep conditionally unstable surface layer $\left(\partial \theta_{\mathrm{e}} / \partial z<0\right)$ most obvious between 40 and $120 \mathrm{~km}$ in the southern leg. The ABL was generally saturated (e.g. most dropsonde RHs are between 95 and 100\%), which means $\theta_{\mathrm{e}}$ is conserved and so this conditionally unstable surface layer will be unstable. The implication is that the relatively warm sea surface was destabilising the atmospheric surface layer through turbulent sensible and latent heat fluxes from the ocean into the atmosphere.

The horizontal gradient in temperature across the jet leads to a horizontal gradient in specific humidity (Figure 5). There was a relatively strong gradient in $q$, 

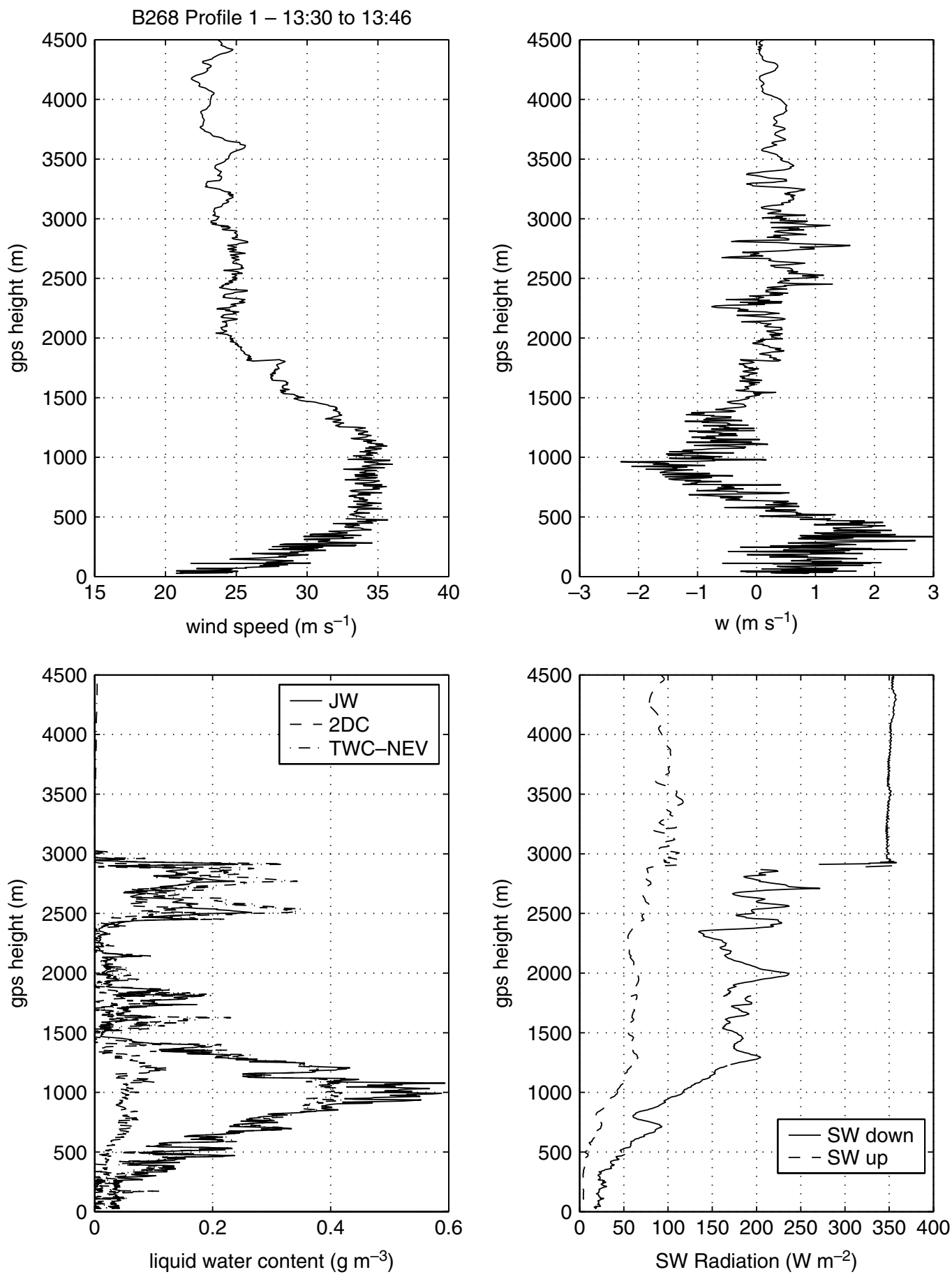

Figure 7. Profiles from flight-level observations during the aircraft's descent at about $40.5^{\circ} \mathrm{W}, 59.4^{\circ} \mathrm{N}$. The panels show: wind speed; vertical velocity $(w)$; cloud liquid water content from the Johnson-Williams instrument, from the 2DC particle imager (25-800 $\mu \mathrm{m})$, and total water content from the Nevzorov instrument (as marked on legend); and short-wave radiation. Note all panels show observations at 1 Hz resolution.

from 3 to $4.5 \mathrm{~g} \mathrm{~kg}^{-1}$, across the jet. There was little change in $q$ along the jet (not shown). Figure 5 illustrates the near saturation of most of the ABL with RH generally between 90 and $100 \%$. The cross-sections show some structure in $\mathrm{RH}$, with generally lower RHs $(<90 \%)$ at the coast, concomitant with the clearer areas in the satellite image of Figure 3. There are layers of very dry air (RH $<40 \%$ ) at the top of the cloud deck in all cross-sections: at $\sim 3000 \mathrm{~m}$ in the northern leg and from 4000 to $3000 \mathrm{~m}$ in the southern leg.
Observations from the aircraft's profile descent (at $40.5^{\circ} \mathrm{W}, 59.4^{\circ} \mathrm{N}$, Figure 7 ) show several distinct changes at a height of $\sim 3000 \mathrm{~m}$, the top of the cloud deck: (1) an increase in turbulence in the horizontal and vertical velocities; (2) a sharp increase in (cloud) liquid water content in the heated-wire instruments (the Johnson-Williams and Nevzorov) and the cloud particle imager (2DC); and (3) sharp changes in downward short-wave ( $\mathrm{SW} \downarrow$ ) radiation, in particular a drop from $350 \mathrm{~W} \mathrm{~m}^{-2}$ above the clouds to $\sim 200 \mathrm{~W} \mathrm{~m} \mathrm{~m}^{-2}$. The $\mathrm{SW} \downarrow$ decreased rapidly 

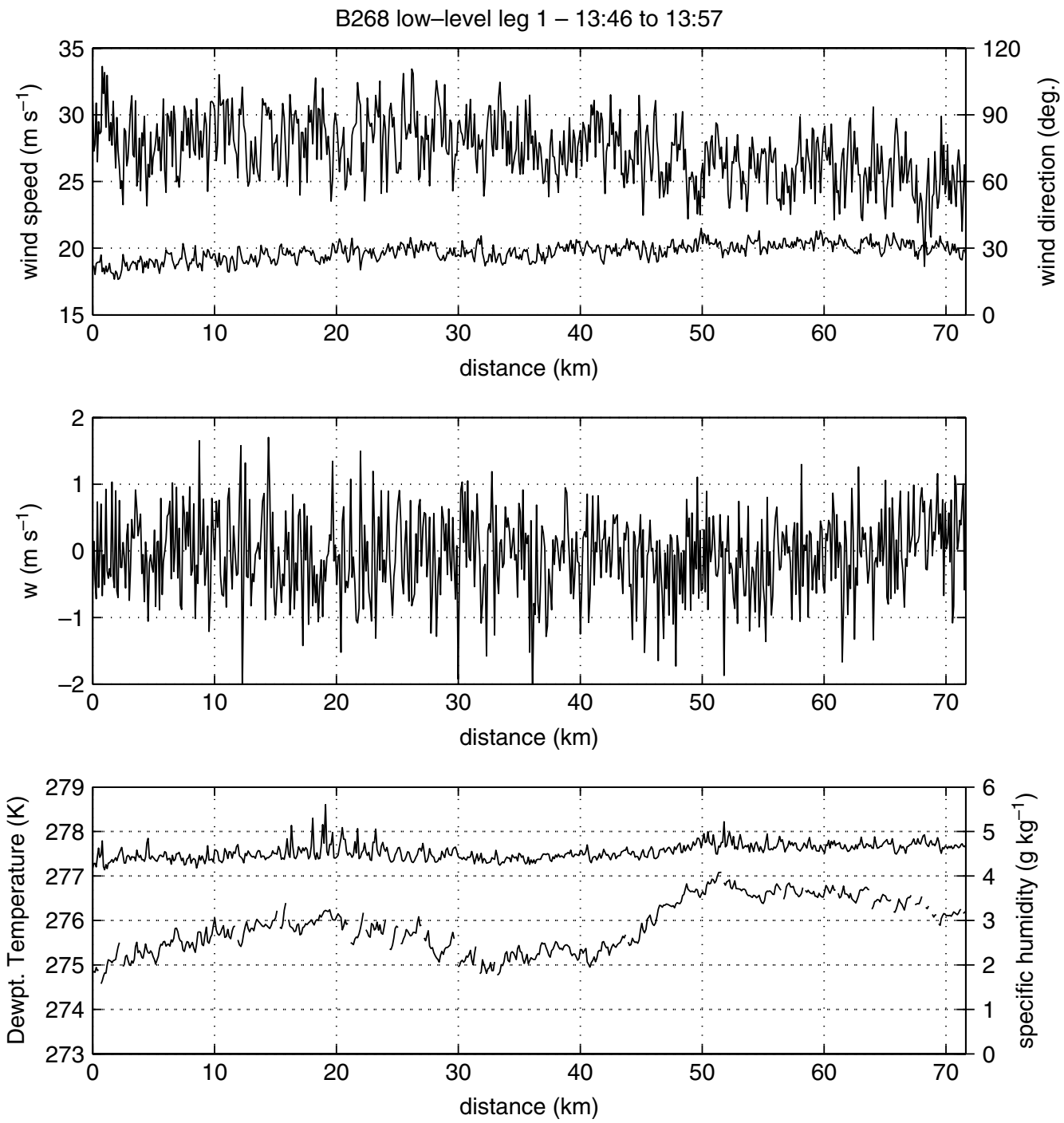

Figure 8. Flight-level observations from low-level leg $1(\sim 40 \mathrm{~m}$ above the sea). The panels show (top) wind speed (upper line) and wind direction (lower line); (middle) vertical velocity $(w)$; and (bottom) dew-point temperature from the General Eastern cooled-mirror instrument (lower line) and specific humidity from the Lyman-alpha absorption hygrometer (upper line). The distance axis is eastwards. Note all panels show observations at $1 \mathrm{~Hz}$ resolution.

again from $\sim 1300 \mathrm{~m}$ to $\sim 300 \mathrm{~m}$, coincident with a second layer of cloud liquid water content. The bottom of this cloud deck was around $300 \mathrm{~m}$ above the sea surface; below the clouds the SW $\downarrow$ was $\sim 25 \mathrm{~W} \mathrm{~m}^{-2}$ and there were still small amounts $\left(<0.05 \mathrm{~g} \mathrm{~m}^{-3}\right)$ of cloud droplets in the air. Precipitation was also evident on the descent, with measurements of about $0.1 \mathrm{~g} \mathrm{~m}^{-3}$ liquid water content and $\sim 1 \times 10^{4}$ particle concentration (per $\mathrm{m}^{3}$ ) on the 2DP particle imager (not shown). However this instrument suffered from intermittent noise during the lower part of the descent and during part of low-level leg 1 (from 1342 to 1352 UTC).

Observations from the profile ascent at $40.3^{\circ} \mathrm{W}, 60.2^{\circ} \mathrm{N}$ show similar features but with a cloud top $\sim 4000 \mathrm{~m}$ above the sea surface (not shown). The cloud liquid water content was about $0.2 \mathrm{~g} \mathrm{~m}^{-3}$ up to $4000 \mathrm{~m}$, but did not reach the peak values of $0.6 \mathrm{~g} \mathrm{~m}^{-3}$ seen during the descent. Precipitation from the 2DP suggests a liquid water content up to $0.1 \mathrm{~g} \mathrm{~m}^{-3}$ and particle concentrations up to $1 \times 10^{4}$ per $\mathrm{m}^{3}$. Examination of the $2 \mathrm{DC}$ particle images suggests the clouds were primarily made up of droplets, but that there were some aggregated particles too, especially higher up. Examination of 2DP images suggests the precipitation was in the form of columns or needles lower down, turning to snow above about $2000 \mathrm{~m}$. Again there was considerable turbulence indicated by increased variance in the horizontal and vertical winds. The aircraft profiles (e.g. Figure 7) illustrate the welldefined jet in horizontal wind speed described earlier and show that there is convergence of mean vertical velocity into the jet, i.e. $w$ was positive below the jet maximum and negative above the jet maximum - although this convergence was less pronounced at the ascent.

Figure 8 illustrates a strong gradient in wind speed with distance along low-level leg 1 (note the $x$-axis is eastwards - away from the jet core). The winds decreased from $\sim 30 \mathrm{~m} \mathrm{~s}^{-1}$ to $\sim 25 \mathrm{~m} \mathrm{~s}^{-1}$ moving out of the jet core. The wind direction veered a little from 20 to 30 degrees. The vertical velocity variance was large compared to the mean value, which was small and actually negative 
Table I. Turbulence and microphysical measurements from the low-level legs of flight B268.

\begin{tabular}{lcccc}
\hline & Leg 1 & Leg 2 & Leg 3 & All legs \\
\hline Heading (degrees) & 300 & 0 & 120 & - \\
Altitude $(\mathrm{m})$ & $41(3.4)$ & $41(3.7)$ & $45(3.6)$ & $42(3.6)$ \\
Wind speed $\left(\mathrm{m} \mathrm{s}^{-1}\right)$ & $27.3(3.0)$ & $28.2(2.7)$ & $26.9(2.7)$ & $27.5(2.8)$ \\
Vertical wind speed $\left(\mathrm{m} \mathrm{s}^{-1}\right)$ & $-0.06(1.3)$ & $-0.14(1.3)$ & $-0.02(1.3)$ & $-0.08(1.3)$ \\
Turbulent kinetic energy $\left(\mathrm{m} \mathrm{s} \mathrm{s}^{2}\right)$ & 6.56 & 6.04 & 6.82 & 6.47 \\
Surface momentum flux $\left(\mathrm{N} \mathrm{m}^{-2}\right)$ & $1.37-1.68$ & $\mathrm{n} / \mathrm{a}$ & $1.50-1.91$ & $1.59(0.23)$ \\
2DP liquid water content $\left(\mathrm{g} \mathrm{m}^{-3}\right)$ & $\mathrm{n} / \mathrm{a}$ & $0.027(0.033)$ & $0.007(0.009)$ & - \\
2DC liquid water content $\left(\mathrm{g} \mathrm{m}^{-3}\right)$ & $0.009(0.009)$ & $0.020(0.017)$ & $0.005(0.010)$ & - \\
JW liquid water content $\left(\mathrm{g} \mathrm{m}^{-3}\right)$ & $\mathrm{n} / \mathrm{a}$ & $0.04(0.03)$ & $0.09(0.02)$ & - \\
2DP precipitation $(\mathrm{mm} / \mathrm{h})$ & $\mathrm{n} / \mathrm{a}$ & 0.486 & 0.025 & - \\
\hline
\end{tabular}

Means and (standard deviations) are tabulated for each low-level leg, and over all three legs where appropriate. The winds and turbulent kinetic energy values are from $32 \mathrm{~Hz}$ data. The surface momentum fluxes are eddy correlation based flux estimates from the 14 runs of Petersen and Renfrew (2009). The 2DP estimated precipitation assumes a fall rate of $5 \mathrm{~m} \mathrm{~s}^{-1}$. Contaminated observations are indicated as n/a (not available).

at this height - see Table I. The specific humidity, $q$, showed a small increase moving out of the jet core and there was an increase in dew-point temperature of $\sim 1 \mathrm{~K}$. Figure 8 illustrates a highly turbulent ABL. The standard deviations of horizontal and vertical winds for this leg were 3.0 and $1.3 \mathrm{~m} \mathrm{~s}^{-1}$ respectively (Table I) and the turbulent kinetic energy per unit mass was $6.56 \mathrm{~m}^{2} \mathrm{~s}^{-2}$, which is highly turbulent compared to typical observations for unstable conditions (e.g. Stull, 1988). Associated with the high winds and turbulence were high surface stresses, e.g. surface momentum fluxes between 1.37 and $1.68 \mathrm{~N} \mathrm{~m}^{-2}$ on this leg. These values are direct eddy correlation measurements for 2-minute runs taken from Petersen and Renfrew (2009). Petersen and Renfrew define 14 runs over the three low-level legs of this flight. The average surface stresses of these 14 runs is $1.59 \mathrm{~N} \mathrm{~m}^{-2}$, with 1 standard deviation $(1 \sigma)=0.23 \mathrm{~N}$ $\mathrm{m}^{-2}$, and an observed range from 1.23 to $1.91 \mathrm{~N} \mathrm{~m}^{-2}$. These surface momentum fluxes are amongst the highest ever directly measured over the ocean (cf. Persson et al., 2005; Petersen and Renfrew, 2009).

These extreme surface stresses were associated with a rather dramatic surface wave field, in particular there was a significant swell, broadly in the downwind direction, with significant wave heights estimated visually to be in the range of 5-10 m. Unfortunately no dedicated high-resolution altimeters were on the aircraft so in situ quantitative wave heights are not presented. Satelliteobserved significant wave heights (SWH) derived from the Jason altimeter are available for three passes on 21 February 2007. Figure 9 shows the locations and times of these passes and plots of the SWH along each pass. One can see the SWH ranging from 3 to $10 \mathrm{~m}$ with 8-9 $\mathrm{m}$ SWHs off the coast of southeast Greenland (in passes 224 and 243) under the highest wind speeds of the ETJ. These SWH values are extremely large compared to climatology. However, they are consistent with coupled atmospheric-wave model simulations that have been carried out for this case (not shown), which will be the subject of future studies. From the $40 \mathrm{~m}$ altitude legs one could see streaks of white caps caused by
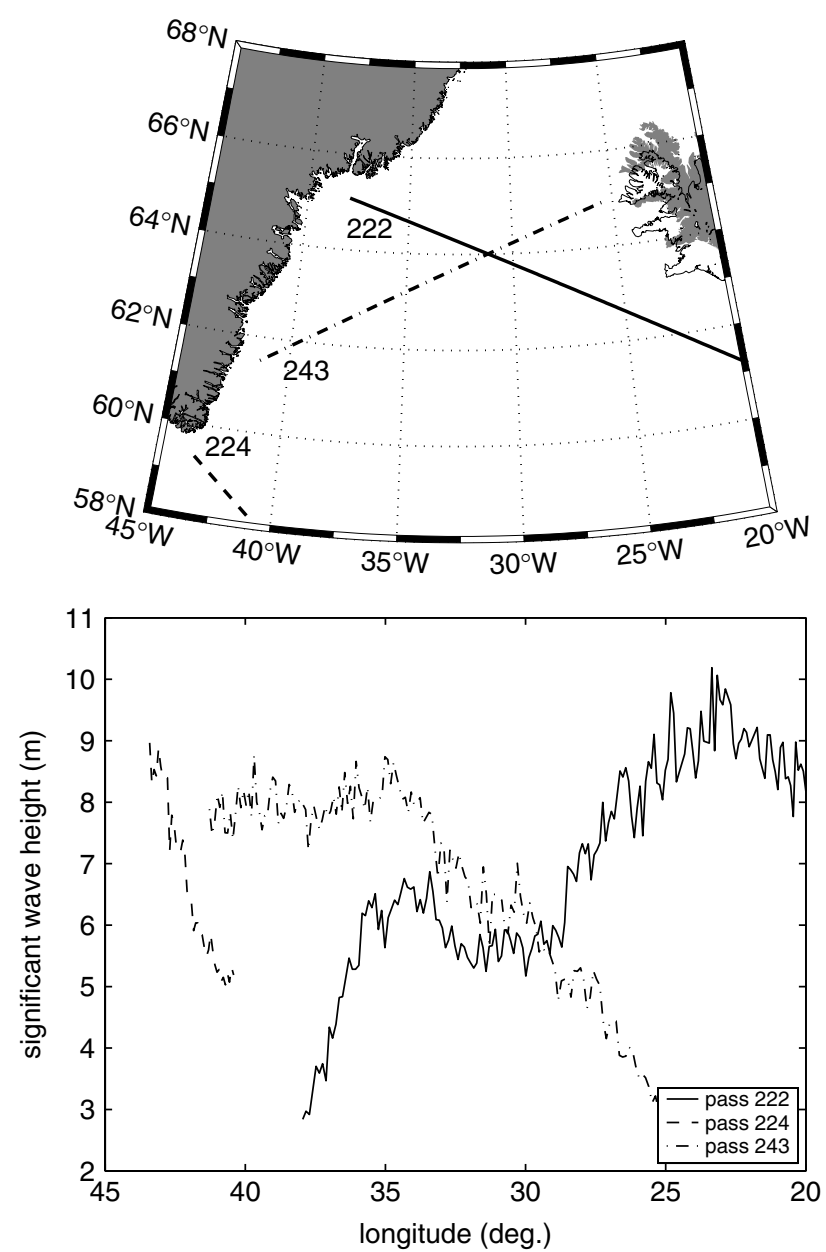

Figure 9. Significant wave heights for three passes of the Jason altimeter on 21 February 2007. The top panel shows the pass location and number. The bottom panel shows significant wave height in metres. The pass times are 0142 UTC (pass 222), 0337 UTC (pass 224) and 2212 UTC (pass 243).

the tops of waves being torn off and there were significant amounts of sea spray in the air. Sea salt aerosol-sized particles were measured using a PCASP (Passive Cavity Aerosol Spectrometer Probe) for the range 0.05-1.5 $\mu \mathrm{m}$ 
and a FFSSP (Fast Forward Scattering Spectrometer Probe) for the range 2-22 $\mu \mathrm{m}$ - see Osborne (2008). Due to precipitation being present on this flight, the FFSSP data may be unreliable as it is not possible to differentiate between sea salt aerosols and splintering precipitation. Nevertheless, Osborne (2008) finds total sea salt aerosol concentrations of $221(1 \sigma=170)$ and $200(1 \sigma=156)$ particles $\mathrm{cm}^{-3}$ for $U_{10}$ of 24 and $23.4 \mathrm{~m} \mathrm{~s}^{-1}$ respectively. These high values of sea salt aerosol concentration would undoubtedly have also been affecting the air-sea exchange of heat and moisture (e.g. see Andreas and DeCosmo, 2002). Investigation of this is an area of ongoing research that is beyond the scope of this paper.

Table I also gives liquid water contents from the 2DP and 2DC particle imagers and the Johnson-Williams heated wire instrument. Note that the Johnson-Williams instrument has a tendency to drift from its baseline during flight conditions and standard practice is to apply an offset determined from periods that are known to be out of cloud. During the low-level legs visual observations suggested the aircraft was largely below cloud base, although there was precipitation falling and visibility was reduced due to some cloud droplets being present. During leg 1 the 2DC measured only very small amounts of liquid water $\left(<0.01 \mathrm{~g} \mathrm{~m}^{-3}\right)$, while the Johnson-Williams measurements were approximately constant (with average value $0.067 \mathrm{~g} \mathrm{~m}^{-3}$ ). On the assumption that this was basically cloud-free air we have applied an offset of $-0.067 \mathrm{~g} \mathrm{~m}^{-3}$ to the Johnson-Williams measurements for the remaining low-level legs. Following this adjustment, Table I shows liquid water content from both cloud-sized droplets and precipitation drops split approximately equally between the 2DC and 2DP (during legs 2 and 3). Note the legaveraged Johnson-Williams liquid water content was approximately equal to the total from the particle imagers (within quoted instrument accuracies). More cloud liquid water and precipitation was measured during leg 2, the north-south leg, than during leg 3. Figure 10 shows the liquid water content from the 2DP (top panel) and the adjusted Johnson-Williams and 2DC (bottom panel). The variability was large, but there were clearly areas of higher precipitation, generally also associated with more cloud droplets, such as the first $10 \mathrm{~km}$ of the leg. For leg 2, the leg-averaged 2DP liquid water contents have been converted into an equivalent precipitation rate of about $0.5 \mathrm{~mm}$ per hour by assuming a fall rate of $5 \mathrm{~m} \mathrm{~s}^{-1}$ for the drops. This is a significant amount of precipitation, amounting to $12 \mathrm{~mm}$ over 24 hours. An area of orographically enhanced precipitation fits well with the established literature for low-level flows forced against a substantial barrier (e.g. Smith, 1979) and has been a feature of previous numerical simulations (e.g. Martin and Moore, 2007; Ohigashi and Moore, 2009).

\section{Synthesis}

To provide a spatial picture of the easterly tip jet's structure, observations from the dropsonde soundings and flight-level data have been synthesised into a set of panels in Figure 11. Observations of wind speed $\left(U_{40 \mathrm{~m}}\right)$, potential temperature $\left(\theta_{40 \mathrm{~m}}\right)$ and specific humidity $\left(q_{40 \mathrm{~m}}\right)$ have been extracted at $40 \mathrm{~m}$ above sea level (i.e. flight level) from each dropsonde sounding and these values have been checked to ensure they are representative of the
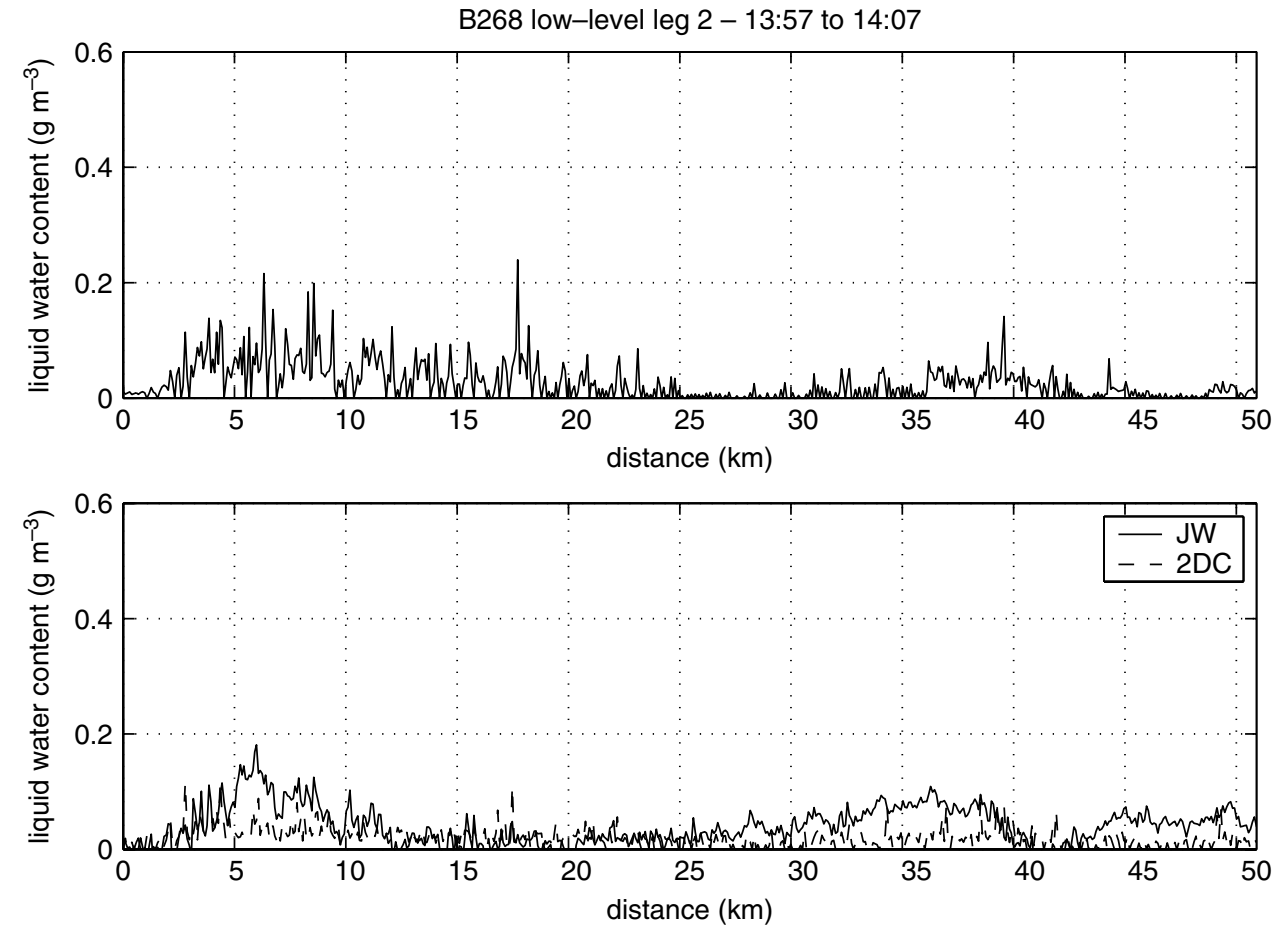

Figure 10. Flight-level observations from low-level leg 2. The panels show (top) liquid water content from the 2DP particle imager (200-6400 $\mu \mathrm{m})$, i.e. precipitation; and (bottom) liquid water content from the Johnson-Williams instrument (upper line) and from the 2DC particle imager $(25-800 \mu \mathrm{m}$; lower line), i.e. cloud droplets. The distance axis is northwards. 
lower ABL. In addition, a $10 \mathrm{~m}$ neutral wind speed $\left(U_{10 \mathrm{~N}}\right)$ has been derived from $U_{40 \mathrm{~m}}$. The flight-level observations have been averaged into 2-minute means - as described in Petersen and Renfrew (2009). Note that as described earlier, the temperature sensors experienced 'wetting' during low-level parts of the flight; so instead of $T$, the observed $T_{\mathrm{d}}$ (adjusted by assuming a constant dew-point depression of $1.3 \mathrm{~K}$ - based on a direct comparison with dropsonde 11) is used to calculate a flight-level $\theta_{40 \mathrm{~m}}$.

Figure 11 illustrates the generally stronger winds towards the Greenland coastline and the downstream acceleration the ETJ underwent as it approached Cape Farewell. The exception was the lower wind speed of the north-westernmost observation, which was several metres per second lower than one might expect, perhaps due to increased drag over the sea ice at this location. The wind vectors illustrate the start of an anticyclonic turning of the ETJ around Cape Farewell. Concomitant with the lowlevel wind jet was a tongue of relatively cold air, some $3-4 \mathrm{~K}$ colder near the coast than $\sim 100 \mathrm{~km}$ offshore.
The cold-air tongue overlies a background meridional temperature gradient from cold to warm down the jet. The cold-air tongue was also relatively dry, with $q_{40 \mathrm{~m}}$ being up to $2 \mathrm{~g} \mathrm{~kg}^{-1}$ lower along the coast. This ETJ structure is qualitatively similar to numerical modelling simulations of other case-studies, for example Martin and Moore (2007), Ohigashi and Moore (2009) and also to the simulations in Part II of this study.

It is of interest to examine QuikSCAT's view of this easterly tip jet event. These scatterometer-based $U_{10 \mathrm{~N}}$ winds have been used extensively in the study of maritime weather and climate: for example, in climatological studies (e.g. Moore and Renfrew, 2005; Sampe and Xie, 2007); to identify small-scale wind features associated with, for example, SST fronts (e.g. Chelton et al., 2004); and in investigations of particular weather system events (e.g. Chelton et al., 2006). Figure 12 shows QuikSCAT $U_{10 \mathrm{~N}}$ from two different retrievals: the RSS (Remote Sensing Systems) geophysical model (e.g. Wentz et al., 2001 and www.remss.com) and the NASA
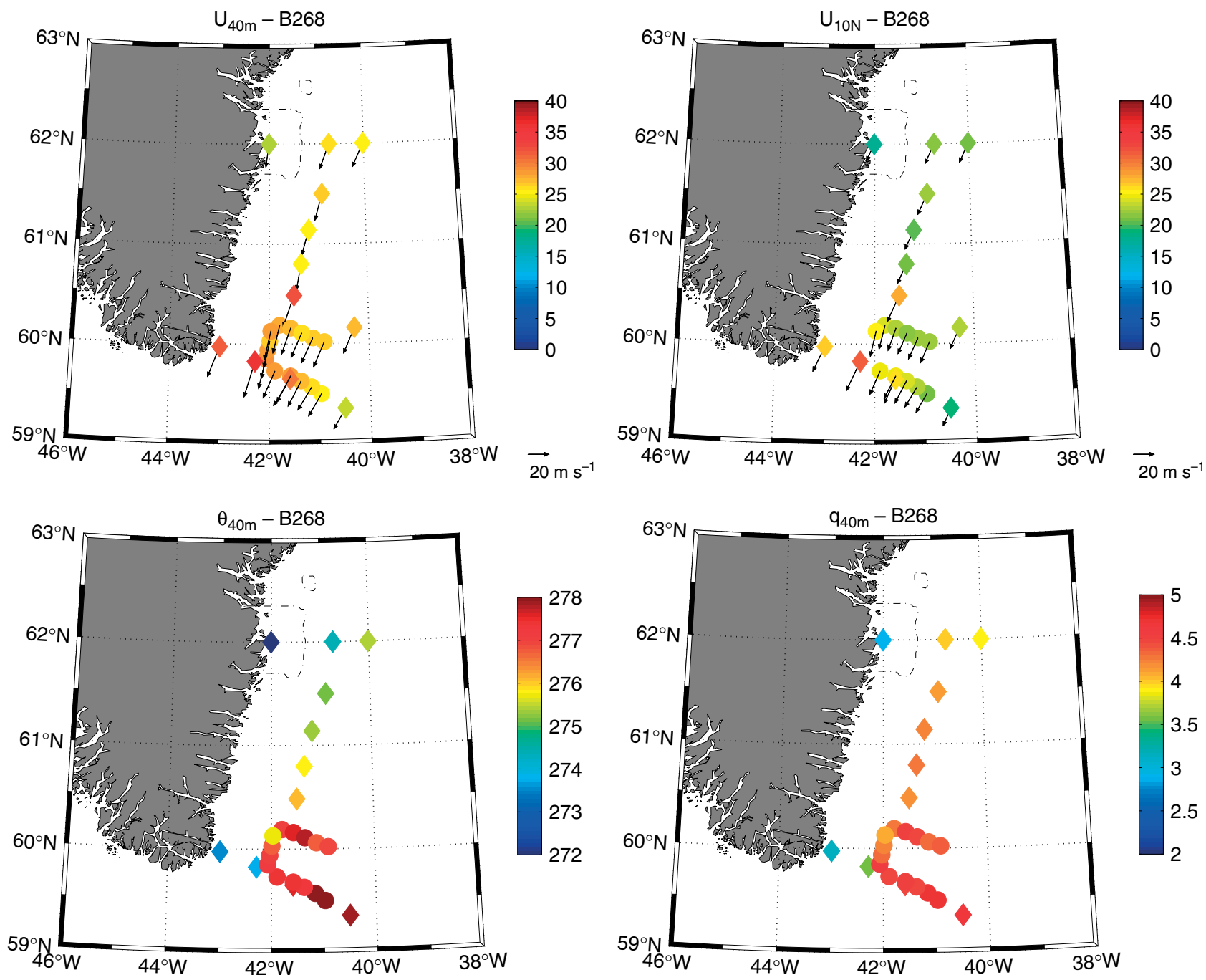

Figure 11. Spatial compilation of flight-level observations (circles) and dropsonde observations (diamonds). The panels show wind speed at flight level $\left(U_{40 \mathrm{~m}}\right)$; wind speed adjusted from flight level to $10 \mathrm{~m}$ assuming neutral conditions $\left(U_{10 \mathrm{~N}}\right)$; potential temperature at flight level $\left(\theta_{40 \mathrm{~m}}\right)$; and specific humidity at flight level $\left(q_{40 \mathrm{~m}}\right)$. Note the flight-level $\theta_{40 \mathrm{~m}}$ values are derived from dew-point temperature observations corrected by $+1.3 \mathrm{~K}$ dew-point depression. Areas of sea ice concentration $>20 \%$ are shown with a dash-dotted contour. The compilation is at approximately 1400 UTC 21 February 2007. 

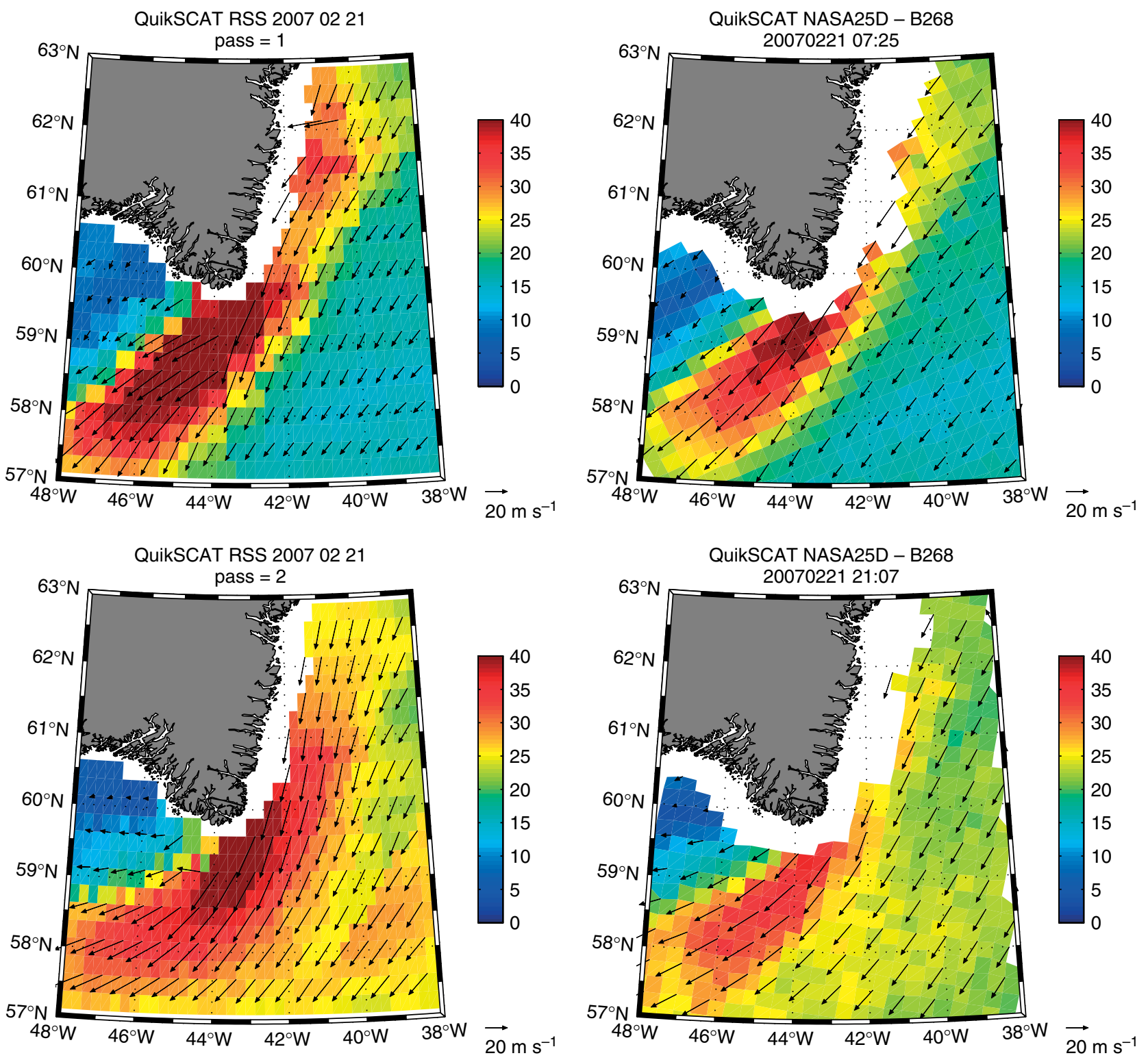

Figure 12. QuikSCAT-derived $U_{10 \mathrm{~N}}$ fields from (top) the morning pass (0725 UTC) and (bottom) the evening pass (2107 UTC) on 21 February 2007. The left-hand panels show $U_{10 \mathrm{~N}}$ using the NASA DIRTH algorithm, the right-hand panels show $U_{10 \mathrm{~N}}$ using the RSS algorithm.

DIRTH (National Aeronautics and Space Administration, Direction Interval Retrieval and Threshold Nudging) model (e.g. JPL, 2006). The RSS product has been re-mapped onto a $0.25^{\circ}$ grid, while the NASA DIRTH (NASA-D) product is a $25 \mathrm{~km} \mathrm{L2B}$ pass product. Retrievals from the morning (0725 UTC) and evening (2107 UTC) passes are shown. In all panels of Figure 12 the ETJ was well-defined, with a strong cross-jet gradient in wind speed towards the Greenland coast, and a less-pronounced along-jet gradient in wind speed. The cross-jet gradient was much tighter in the earlier passes. In the evening passes the ambient north-easterly flow was generally a little stronger (by $\sim 10 \mathrm{~m} \mathrm{~s}^{-1}$ ). To the southwest of Greenland there is a well-defined wake region, where $U_{10 \mathrm{~N}}<10 \mathrm{~m} \mathrm{~s}^{-1}$, as has been seen in numerical simulations (e.g. Ohigashi and Moore, 2009). There was generally a good correspondence between the two retrieval algorithms at each time, as one would expect, but there are some systematic differences. The NASA-D algorithm's sea-ice mask goes further offshore, resulting in fewer observations near the coastline. The RSS algorithm returns generally higher $U_{10 \mathrm{~N}}$ values, especially in the jet core, i.e. where the winds were highest. The QuikSCAT panels can also be compared to $U_{10 \mathrm{~N}}$ in Figure 11, compiled from dropsonde and flight-level observations between 1220 and 1430 UTC, so closer to the morning pass. Qualitatively the ETJ structure was very similar - a strong cross-jet gradient and a less-pronounced along-jet wind gradient - and even the acceleration between the northern and southern flight-level observations was seen in the QuikSCAT winds. But quantitatively one can see the QuikSCAT winds overestimate the observations by typically about $5 \mathrm{~m} \mathrm{~s}^{-1}$. This QuikSCAT overestimation is representative of a larger comparison of QuikSCAT winds against all the low-level GFDex observations carried out by Renfrew 


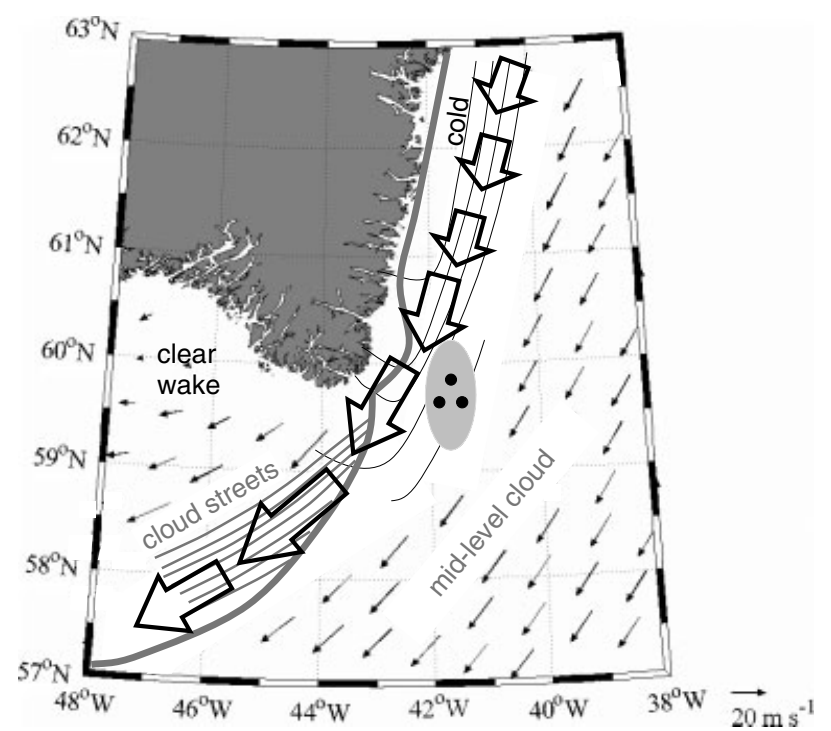

Figure 13. Schematic of a typical easterly tip jet. The high winds associated with the jet core are shown with open arrows. The cold and dry tongue off the southeast Greenland coast is shown with solid contours. There is mid-level cloud filling the south-eastern half of the domain, the edge of which is marked with a thick grey line; underneath this, cloud streets are marked with thinner grey lines. An area of precipitation is marked with a light grey oval. Selected QuikSCAT wind vectors are used as a background to give a sense of the low-level winds surrounding the jet core.

et al. (2009). They find relatively large root-mean-square errors of 3.3 and $1.9 \mathrm{~m} \mathrm{~s}^{-1}$ and linear regression slopes of 1.39 and 1.06 for QuikSCAT winds against observations (for the RSS and NASA-D algorithms respectively); indicating an overestimate in retrieved wind speed at higher wind speeds. Similar regression statistics were found in a comparison against buoy observations in this location by Moore et al. (2008). In short, the QuikSCAT winds seem to provide an accurate spatial picture of these high wind-speed features, but the retrieved $U_{10 \mathrm{~N}}$ values may well be overestimates for the higher wind speeds.

The comprehensive observations of this case motivate a schematic of a 'typical' easterly tip jet event in Figure 13. Although based on a synthesis of the observations presented here - i.e. for the 21 February 2007 case - this schematic is generally representative of other ETJ cases described in the literature via numerical simulations and satellite data, for example those of Moore and Renfrew (2005), Martin and Moore (2007) and Ohigashi and Moore (2009) are rather similar even for the cloud patterns. Figure 13 illustrates the high winds associated with the ETJ core as open arrows. The length of these arrows is proportional to the low-level wind speed, based on a synthesis of the aircraft observations (Figure 11) and the QuikSCAT observations (Figure 12). The acceleration along the jet and the anticyclonic turning of the jet are clear. The tongue of cold and dry ABL air (cf. Figures 5 and 11) is shown as black contours hugging the coast of southeast Greenland. Mid-level cloud (3-4 km deep) fills the south-eastern half of the domain (cf. Figure 3), the edge of this cloud being shown with a thick grey line. Note the cloud-free slot immediately to the east of Cape Farewell. The ABL cloud streets that emanate from under the mid-level cloud are illustrated with thinner grey lines. The observed precipitation is shown as a small (grey) patch just to the east of the jet core, although it is worth emphasising that the extent of the precipitation is not known from our relatively short low-level aircraft legs. The precipitation being on the flank of the jet core was a feature of the cloud-resolving modelling simulations of Ohigashi and Moore (2009) and was also noted in the operational forecasts during the GFDex campaign. As a background to the schematic, selected wind vectors from a QuikSCAT image are included. These highlight the increase of winds towards the coast; the anticyclonic turning along the jet; and the area of very low winds to the southwest of Greenland in the cloud-free wake region (cf. Figure 3).

\section{Conclusions}

The first comprehensive observations of an easterly tip jet case off Cape Farewell, Greenland, have been presented and discussed. The in situ observations reveal an acceleration down the jet and an anticyclonic turning around Cape Farewell - as found in previous modelling and satellite-based studies. The low-level jet had its peak winds, of almost $50 \mathrm{~m} \mathrm{~s}^{-1}$, about $600-800 \mathrm{~m}$ above sea level and at the coast. The depth of the jet increased with wind speed, from $\sim 1500 \mathrm{~m}$ to $\sim 2500 \mathrm{~m}$ as the peak winds increased from 30 to $50 \mathrm{~m} \mathrm{~s}^{-1}$. The jet was associated with a tongue of cold and dry air hugging the coastline and occupying the lower half of the ABL. The lower ABL was generally conditionally unstable, suggesting positive turbulent heat fluxes forcing a convective ABL. The high winds resulted in a highly turbulent ABL and extremely high surface stresses - amongst the highest directly observed over the ocean. The region was generally cloudy to the southeast of Greenland, breaking away to the south of Cape Farewell to reveal cloud streets in the ABL. To the southwest of Greenland was a cloud-free wake. Precipitation was observed and estimated at about $0.5 \mathrm{~mm}$ per hour. The in situ observations are qualitatively consistent with QuikSCAT images of the event and correspond well spatially; however, a quantitative comparison suggests the scatterometer winds overestimate $U_{10 \mathrm{~N}}$ for the higher wind speeds.

These in situ observations provide a unique snapshot of a strong easterly tip jet event. As noted earlier, the observations are broadly consistent with previous climatological and NWP modelling studies of these weather systems. However, a number of new and interesting features have also been brought to light. The observations provide unique validation data and this is exploited in Part II of this study, which focuses on numerical simulations of this event and a thorough dynamical analysis of the forcing mechanisms behind easterly tip jets.

\section{Acknowledgements}

We would like to thank all at the FAAM for enabling the GFDex field campaign. This study was funded 
by the Natural Environmental Research Council (grant NE/C003365/1). GFDex also received funding from the Canadian Foundation for Climate and Atmospheric Sciences (GR-641); while the EUFAR (European Fleet for Airborne Research) and EUCOS (European Coordinated Observing System) schemes contributed additional resources to the field campaign. The assistance of the Dundee Satellite Receiving Station, part of NERC's Earth Observation Data Acquisition and Analysis Service, is gratefully acknowledged. IAR would like to thank Alan Woolley (FAAM), Phil Brown and Dave Kindred (Met Office) for useful discussions on data quality. This study was partly carried out at the University of Toronto during a period of sabbatical leave for the lead author, for which he would like to thank the Department of Physics and NERC for financial contributions. We would like to thank T. Ohigashi for early versions of some graphics, $H$. Adiwidjaja for extracting the Jason altimeter data and G.N. Petersen for useful comments on an early draft of this paper.

\section{References}

Andreas EL, DeCosmo J. 2002. The signature of sea spray in the HEXOS turbulent heat flux data. Boundary-Layer Meteorol. 103 303-333.

Atkinson BW, Zhang JW. 1996. Mesoscale shallow convection in the atmosphere. Rev. Geophys. 34: 403-431.

Barstad I, Grønås S. 2005. Southwesterly flows over southern Norway - Mesoscale sensitivity to large-scale wind direction and speed. Tellus 57A: 136-152.

Brümmer B. 1997. Boundary layer mass, water, and heat budgets in wintertime cold-air outbreaks from the Arctic sea ice. Mon. Weather Rev. 125: 1824-1837.

Cappelen J, Jørgensen BV, Laursen EV, Stannius LS, Thomsen RS 2001. 'The observed climate of Greenland, 1958-99, with climatological standard normals, 1961-90.' Danish Meteorological Institute Tech. Rep. 00-18, 149 pp.

Chelton DB, Schlax MG, Freilich MH, Milliff RF. 2004. Satellite measurements reveal persistent small-scale features in ocean winds. Science 303: $978-983$.

Chelton DB, Freilich MH, Sienkiewicz JM, Von Ahn JM. 2006. On the use of QuikSCAT scatterometer measurements of surface winds for marine weather prediction. Mon. Weather Rev. 134: 2055-2071.

Doyle JD, Shapiro MA. 1999. Flow response to large-scale topography: The Greenland tip jet. Tellus 51A: 728-748.

Egger J. 2006. Winter time flow over and around Greenland: Trajectories related to torques. Tellus 58A: 584-592.

Godske CL, Bergeron T, Bjerknes J, Bundgaard RC. 1957. Dynamic meteorology and weather forecasting. American Meteorological Society, and Carnegie Institution of Washington: Washington, DC, USA.

Hay C, Moore GWK, Pickart RS. 2009. A case study of a Greenland lee cyclogenesis event and the subsequent spawning of a tip jet. Tellus, submitted.

JPL. 2006. 'QuikSCAT science data product: User's manual, version 3.0, D-18053 - Rev A. Overview and geophysical data products.' Jet Propulsion Laboratory: Pasadena, California, USA.

Martin C. 2007. 'The ASPEN user manual' Available from National Center for Atmospheric Research: Boulder, Colorado, USA, 61 pp.

Martin R, Moore GWK. 2007. Air-sea interaction associated with a Greenland reverse tip jet. Geophys. Res. Lett. 34: L24802, DOI:10.1029/2007GL031093

Moore GWK. 2003. Gale force winds over the Irminger Sea to the east of Cape Farewell, Greenland. Geophys. Res. Lett, 30: 1894 DOI: 10.1029/2003GL018012

Moore GWK, Renfrew IA. 2005. Tip jets and barrier winds: A QuikSCAT climatology of high wind speed events around Greenland. J. Climate 18: 3713-3725.

Moore GWK, Pickart RS, Renfrew IA. 2008. Buoy observations from the windiest location in the world ocean, Cape Farewell, Greenland. Geophys. Res. Lett. 35: L18802, DOI:10.1029/2008GL034845
Ohigashi T, Moore GWK. 2009. Fine structure of a Greenland reverse tip jet: A numerical simulation. Tellus 61A: 512-526.

Ólafsson H, Bougeault P. 1996. Nonlinear flow past an elliptic mountain ridge. J. Atmos. Sci. 53: 2465-2489.

Ólafsson H, Bougeault P. 1997. The effect of rotation and surface friction on orographic drag. J. Atmos. Sci. 54: 193-210.

Orr A, Hanna E, Hunt JCR, Cappelen J, Steffen K, Stephens AG. 2005. Characteristics of stable flows over southern Greenland. Pure Appl. Geophys. 162: 1747-1778.

Osborne SR. 2008. 'A validation study of the sea salt parametrisation within the Unified Model using aircraft observations.' OBR Technical Note No. 72. Met Office: Exeter, UK.

Outten SD, Renfrew IA, Petersen GN. 2009. An easterly tip jet off Cape Farewell, Greenland. II: Simulations and dynamics. $Q$. J. $R$. Meteorol. Soc. 135: 1934-1949.

Parish TR. 1982. Barrier winds along the Sierra Nevada mountains. $J$. Appl. Meteorol. 21: 925-930.

Parish TR. 1983. The influence of the Antarctic Peninsula on the wind field over the western Weddell Sea. J. Geophys. Res. 88(C4): 2684-2692.

Persson POG, Hare JE, Fairall CW, Otto WD. 2005. Air-sea interaction processes in warm and cold sectors of extratropical cyclonic storms observed during FASTEX. O. J. R. Meteorol. Soc. 131: 877-912.

Petersen GN, Renfrew IA. 2009. Aircraft-based observations of air-sea fluxes over Denmark Strait and the Irminger Sea during high wind speed conditions. Q. J. R. Meteorol. Soc. 135: 2030-2045.

Petersen GN, Ólafsson H, Kristjánsson JE. 2003. Flow in the lee of idealized mountains and Greenland. J. Atmos. Sci. 60: 2183-2195.

Petersen GN, Kristjánsson JE, Ólafsson H. 2005. The effect of upstream wind direction on atmospheric flow in the vicinity of a large mountain. Q. J. R. Meteorol. Soc. 131: 1113-1128.

Petersen GN, Renfrew IA, Moore GWK. 2009. An overview of barrier winds off southeastern Greenland during the Greenland Flow Distortion experiment. Q. J. R. Meteorol. Soc. 135: 1950-1967.

Pickart RS, Spall MA, Ribergaard MH, Moore GWK, Milliff RF. 2003. Deep convection in the Irminger Sea forced by the Greenland tip jet. Nature 424: $152-156$.

Pierrehumbert RT, Wyman B. 1985. Upstream effects of mesoscale mountains. J. Atmos. Sci. 42: 977-1003.

Renfrew IA, Moore GWK. 1999. An extreme cold-air outbreak over the Labrador Sea: Roll vortices and air-sea interaction. Mon. Weather Rev. 127: 2379-2394.

Renfrew IA, Moore GWK, Kristjánsson JE, Ólafsson H, Gray SL, Petersen GN, Bovis K, Brown PRA, Føre I, Haine T, Hay C, Irvine EA, Lawrence A, Ohigashi T, Outten S, Pickart RS, Shapiro M, Sproson D, Swinbank R, Woolley A, Zhang S. 2008. The Greenland Flow Distortion experiment. Bull. Am. Meteorol. Soc. 89: $1307-1324$

Renfrew IA, Petersen GN, Sproson DAJ, Moore GWK, Adiwidjaja H, Zhang S, North R. 2009. A comparison of aircraft-based surfacelayer observations over Denmark Strait and the Irminger Sea with meteorological analyses and QuikSCAT winds. Q. J. R. Meteorol. Soc. 135: 2046-2066.

Revell MJ, Copeland JH, Larsen HR, Wratt DS. 2002. Barrier jets around the Southern Alps of New Zealand and their potential to enhance alpine rainfall. Atmos. Res. 61: 277-298.

Sampe T, Xie S-P. 2007. Mapping high sea winds from space: A global climatology. Bull. Am. Meteorol. Soc. 88: 1965-1978.

Schween JH, Kuettner J, Reinert D, Reuder J, Wirth V. 2007. Definition of 'banner clouds' based on time lapse movies. Atmos. Chem. Phys. 7: 2047-2055.

Schwerdtfeger W. 1975. The effect of the Antarctic Peninsula on the temperature regime of the Weddell Sea. Mon. Weather Rev. 103: 45-51.

Skeie P, Grønås S. 2000. Strongly stratified easterly flows across Spitsbergen. Tellus 52A: 473-486.

Smith RB. 1979. The influence of mountains on the atmosphere. $A d v$. Geophys. 21: 87-230.

Stull RB. 1988. An introduction to boundary layer meteorology. Kluwer Academic Publishers: Dordrecht

Våge K, Pickart RS, Moore GWK, Ribergaard MH. 2008. Winter mixed layer development in the central Irminger Sea: The effect of strong, intermittent wind events. J. Phys. Oceanogr. 38: 541-565.

Wentz FJ, Smith DK, Mears CA, Gentemann CL. 2001. 'Advanced algorithms for QuikSCAT and SeaWinds/AMSR.' Pp 1079-1081 in Proceedings of International Geoscience and Remote Sensing Symposium 2001, Sydney, Australia, 9-13 July 2001. IEEE. 